\title{
Faktor Risiko Remaja Menjadi Pelaku Kekerasan: A Literature Review
}

\author{
Munqidz Zahrawaani \\ Program Studi Magister Ilmu Keperawatan, Fakultas Ilmu Keperawatan, Universitas Indonesia; \\ zmunqidz@yahoo.co.id (koresponden) \\ Nani Nurhaeni \\ Program Studi Magister Ilmu Keperawatan, Fakultas Ilmu Keperawatan, Universitas Indonesia
}

\section{ABSTRACT}

Violence committed by adolescents is a serious public health problem. Violent behavior is a condition or moment that shows part of behavior from individuals which attack others people or a form of behavior directed at others to maintain power or control. Children and adolescents who experience persecution or traumatic experiences continuously tend to be criminals as adults, but need more investigated and research to explore factors that cause adolescents become perpetrators of violence. Nurses are health workers who must be involved in primary prevention efforts in preventing violent behavior by adolescents. The purpose of this study is to examine the factors that cause adolescents to become perpetrators of violence. This literature review had processed based on academic journals published from 2014 to 2019 starting from Proquest, PubMed and Google Scholar. The results of the study found that the main points that cause adolescents has been perpetrators of violence are drug and alcohol abuse, mental health, poor family relationships and trauma due to violence to neglect of adolescents. The analyzed resulted will provide advice, input and tips for parents and health professionals to take further action on the child. This review literature (expected to be a reference material for further research

Keywords: child abuse; adolescence; nursing

\section{ABSTRAK}

Kekerasan yang dilakukan remaja merupakan masalah kesehatan masyarakat yang serius. Perilaku kekerasan merupakan suatu kondisi atau keadaan yang menunjukkan perilaku individu yang melakukan penyerangan terhadap orang lain atau suatu bentuk perilaku yang ditujukan kepada orang lain untuk mempertahankan kekuasaan atau kontrol. Anak dan remaja yang mengalami penganiayaan atau pengalaman traumatis secara terus menerus cenderung akan menjadi pelaku kejahatan pada saat dewasa, tetapi perlu diteliti lebih lanjut faktor faktor yang menyebabkan remaja menjadi pelaku kekerasan. Perawat merupakan tenaga kesehatan yang harus terlibat dalam upaya pencegahan primer dalam mencegah perilaku kekerasan yang dilakukan remaja. Tujuan penelitian ini adalah untuk menelaah faktor faktor yang menyebabkan remaja menjadi pelaku kekerasaan. Metode penelitian yang digunakan adalah literature review yang diolah berdasarkan jurnal akademis yang dipublikasikan dari tahun 2014 sampai 2019 mulai dari Proquest, PubMed dan Google Scholar. Hasil telaah ditemukan bahwa poin utama yang menyebabkan remaja menjadi pelaku kekerasan adalah penyalahgunaan narkoba dan alKohol, kesehatan mental, hubungan keluarga yang tidak baik dan trauma akibat kekerasan sampai penelantaran remaja. hasil analisis akan memberikan saran, masukkan dan tips bagi orang tua dan tenaga kesehatan untuk melakukan tindakan selanjutnya pada anak. Literatur review ini diharapkan dapat menjadi bahan acuan bagi penelitian selanjutnya.

Kata kunci: kekerasan pada anak; remaja; perawatan

\section{PENDAHULUAN}

Remaja melakukan lebih dari $50 \%$ penyerangan yang serius ${ }^{(1)}$, meskipun angka ini sudah mengalami penurunan sebanyak 17\% dari tahun 2000 pelaku kejahatan anak masih berada di 15\% dari semua jenis kejahatan $^{(2)}$. Anak dan remaja yang dianiaya secara terus menerus cenderung akan menjadi pelaku kejahatan pada saat dewasa. Penelitian Ryan (2013) dengan beragam partisipan mulai dari 24\% perempuan, $13 \%$ campuran Afrika-Amerika dan 5\% Amerika native dan semua remaja berisiko tinggi melakukan kekerasan menemukan bahwa pelaku kekerasan usia remaja ternyata memiliki riwayat ditelantarkan oleh orang tua, keluarga atau caregivernya ${ }^{(2)}$.

Indonesia memiliki populasi sekitar 61 juta anak berusia 0-17 tahun, jadi merawat anak berarti merawat dua puluh dua persen dari keseluruhan jumlah penduduk Indonesia ${ }^{(3)}$. Kekerasan yang terjadi pada anak di Indonesia terus mengalami peningkatan setiap tahunnya, tercatat pada tahun 2011 terdapat sebanyak 216 kasus yang meningkat menjadi dua kali lipat pada tahun 2012 menjadi 412 kasus $^{(3)}$. Pada tahun 2014 terdapat 656 kasus kekerasan pada anak baik sebagai korban maupun pelaku, pelaku kekerasan fisik pada kelompok umur 13-17 tahun pada laki laki maupun perempuan masing masing sebesar 73, 11\% dan 74, 37\% dan dilakukan oleh teman di sekolah ${ }^{(3)}$. UNICEF 2015 menemukan bahwa kekerasan terhadap anak terjadi secara luas di Indonesia, 
40\% anak berusia 13-15 tahun melaporkan pernah diserang secara fisik sedikitnya satu kali dalam setahun dan $50 \%$ anak melaporkan di bully disekolah ${ }^{(4)}$.

Masalah kesehatan mental seperti trauma merupakan masalah yang ditemukan pada populasi remaja yang pernah melakukan kekerasan ${ }^{(5)}$. Anak yang sering mengalami penganiayaan dari orang tua juga berisiko berperilaku agresif yang mengarah kepada kekerasan ${ }^{(6)}$. Penelitian membuktikan bahwa diantara anak pelaku kekerasan sebenarnya merupakan anak yang pernah mengalami kekerasan fisik dan perlakuan tidak menyenangkan yang mengarahkan mereka kepada sebuah pemikiran bahwa perilaku kekerasan adalah hal yang wajar untuk dijadikan kebiasaan ${ }^{(7)}$. Hasil penelitian menunjukkan bahwa $45 \%$ dari $90 \%$ pelaku kekerasan remaja pernah menyaksikan kekerasan dan mengalami trauma akibat suatu peristiwa. Penyebab trauma yang dilaporkan oleh pelaku kekerasan remaja antara lain karena kecelakaan, penyakit yang menimbulkan trauma, bencana alam dan 30\% dari 264 responden merupakan korban dari kekerasan termasuk kekerasan fisik dan pelecehan seksual $^{(7)}$. Penelitian lain juga menjelaskan bahwa ada hubungannya antara perilaku kekerasan dan status sosial ekonomi keluarga pelaku ${ }^{(8)}$.

Pelecehan dan penganiayaan anak mencakup berbagai topik, termasuk faktor risiko, prevalensi, hasil pelecehan anak, respons profesional, dan tumpang tindih dengan kekerasan dalam rumah tangga. Studi prevalensi sering memetakan berbagai jenis penganiayaan, mengikuti klasifikasi dari empat jenis yang paling umum: pelecehan seksual, pelecehan fisik, pelecehan emosional/psikologis, dan penelantaran ${ }^{(9)}$. Penelitian terbaru berfokus pada pelecehan seksual anak, dengan paling sedikit penekanan pada pelecehan emosional dan psikologis dan penelantaran ${ }^{(9)}$.

Tisdale (2019) menyatakan definisi dari tindakan kekerasan adalah setiap tindakan yang ditargetkan pada orang lain, yang menyakiti, menakut-nakuti atau melanggar, membuat orang lain melakukan sesuatu yang bertentangan dengan kehendak mereka, atau berhenti melakukan hal yang mereka inginkan ${ }^{10}$. Meskipun agak luas, definisi yang diungkapkan oleh Tisdale (2019) mencakup berbagai perilaku dan sesuai dalam riset tentang remaja sebagai pelaku kekerasan ${ }^{(10)}$.

Faktor sosial yang menciptakan motivasi yang mengantarkan terjadinya kekerasan seperti sikap masyarakat yang permisif (membolehkan) terjadinya kekerasan pada perempuan dan anak, kontrol orangtua yang sangat dominan dalam mengambil keputusan dan pembatasan terhadap kebebasan anak, lingkungan kumuh dan padat penduduk serta keterpaparan terrhadap kekerasan ${ }^{(11)}$.

Stimmel dan Cruise (2014) pernah menemukan beberapa hal terkait munculnya pelaku kekerasan pada remaja yaitu ${ }^{(7)}$ :

1. Paparan stress dan trauma yang dialami berulang kali

2. Remaja mengalami pengalaman traumatis dalam kurun waktu lebih dari satu tahun

3. Pengalaman trauma yang sudah mengarah kepada gejala depresi dan kecemasan yang lebih tinggi

4. Menyaksikan perilaku kekerasan atau berada didalam suatu lingkungan dengan paparan kekerasan yang sangat mengganggu

Tuliah (2018) menganalisa teori Alfred Schutz yang menyatakan bahwa motif masa lalu dan masa kini merupakan dua hal yang mendukung seseorang menjadi pelaku kekerasan ${ }^{(12)}$. Motif masa lalu berupa sosialisasi dari orang tua dan keluarga yang kurang terutama dalam pemahaman religius, sedangkan motif masa kini (in order to motif) berupa alasan yang dikemukakan oleh pelaku misalnya kurangnya komunikasi dengan anggota keluarga dan sering menonton tayangan kekerasan melalui gadget atau media sosial. Motif masa lalu (because motif) merupakan motif awal dimana pelaku melakukan perbuatannya dengan tambahan motif saat ini (in order to motif) sehingga niat melakukannya semakin kuat dilakukan oleh pelaku.

Menghadapi banyaknya kasus kekerasan pada remaja ini masyarakat memberikan respon dengan mengharapkan tenaga professional seperti perawat terlibat dalam, pencegahan, identifikasi dan berespon terhadap kekerasan remaja. Beberapa fakta yang menunjukkan betapa pentingnya peran perawat antara lain karena perawat sering berinteraksi dengan anak dan keluarga, baik dipelayanan primer maupun sekunder ${ }^{(13)}$, perawat kurang memiliki pengetahuan dan kepercayaan diri untuk secara efektif menangani kekerasan pada anak, defisit pengetahuan ini mengakibatkan perawat harus mengandalkan profesi lain untuk berespon terhadap kekerasan pada anak, layanan perlindungan anak belum dipastikan mampu memberikan hasil bimbingan yang positif pada anak dan perawat juga harus berperan dalam memenuhi tugas etik keperawatan dalam menjaga remaja dari perilaku kekerasan ${ }^{(14)}$. Penelitian lebih lanjut diperlukan untuk meningkatkan kemampuan perawat dalam menghadapi pelaku kekerasan remaja.

\section{METODE}

Metode penelitian yang kami gunakan disini adalah literature review dengan menggunakan jurnal dari nasional maupun internasional melalui database yang sudah terakreditasi seperti Proquest, PubMed, Google scholar dengan kata kunci child abuse, adolescence, dan nursing. Kriteria inklusi yang digunakan oleh penulis adalah dengan membatasi artikel atau jurnal yang digunakan dalam range tahun 2014 sampai 2019, jurnal mempunyai judul dan isi yang sesuai dengan tujuan penelitian, full text, dan keterkaitan dengan keperawatan . 
Hal ini bertujuan untuk kemutakhiran hasil riset dan keterbaruan pengambilan database. Kriteria eksklusi: (1) artikel tidak memiliki struktur yang lengkap; (2) berbentuk review artikel.

\section{HASIL}

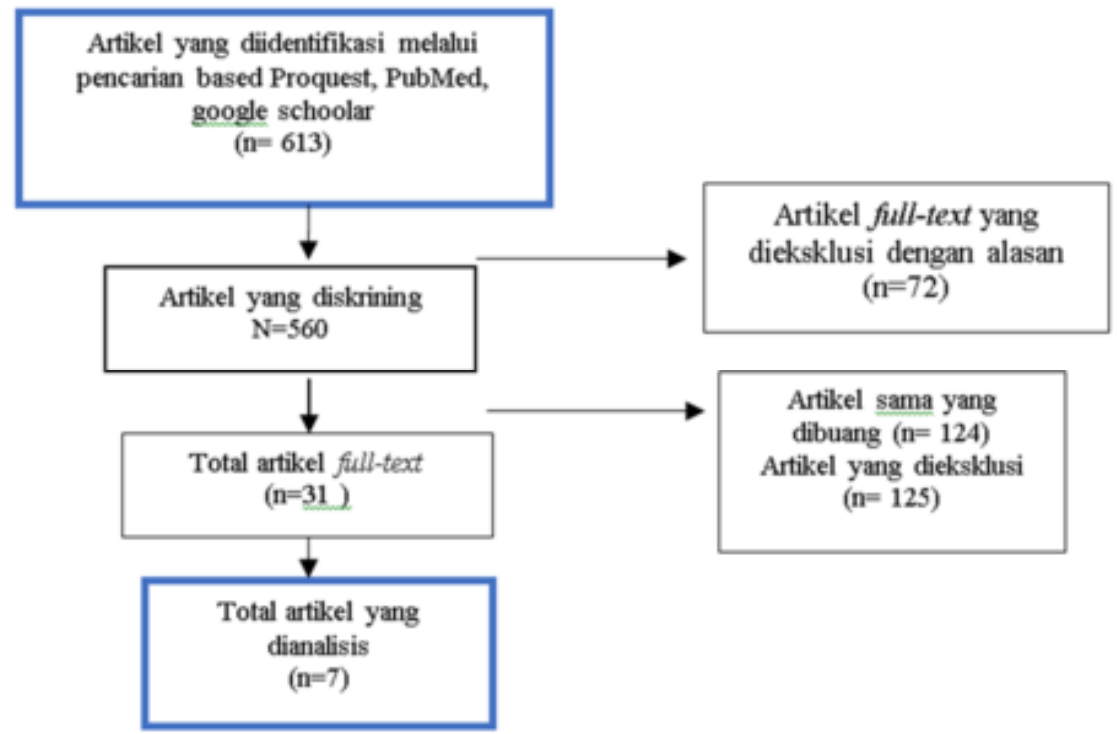

Gambar 1. Bagan Alur Review artikel yang diteliti

Tabel 1. Tabel review artikel

\begin{tabular}{|c|c|c|c|c|}
\hline Artikel & Desain & Sampel & Prosedur pengumpulan data & Hasil \\
\hline $\begin{array}{l}\text { Stimmel \& } \\
\text { Cruise } \\
(2014)^{7}\end{array}$ & $\begin{array}{l}\text { Kualitatif } \\
\text { deskriptif }\end{array}$ & $\begin{array}{l}\text { 66 laki laki berusia 12-16 } \\
\text { tahun di Pusat Tahanan } \\
\text { Remaja dengan criteria } \\
\text { inklusi: } \\
\text { Pernah melakukan } \\
\text { penyerangan } \\
\text { Pernah terlibat dalam } \\
\text { kepemilikan senjata } \\
\text { Pernah melakukan } \\
\text { elanggaran masa percobaan }\end{array}$ & $\begin{array}{l}\text { Wawancara dilakukan disebuah } \\
\text { ruangan khusus di dalam Pusat } \\
\text { Tahanan Remaja } \\
\text { Wawancara diawali dengan } \\
\text { pengumpulan data demografi } \\
\text { partisipan dan latar belakang } \\
\text { mereka masuk tahanan remaja }\end{array}$ & $\begin{array}{l}\text { Sebanyak } 86,4 \% \text { remaja pernah mengalami } \\
\text { setidaknya satu peristiwa yang traumatis, } 71 \% \\
\text { mengalami setidaknya dua peristiwa traumatis, } \\
\text { remaja ini juga pernah menyaksikan kekerasan } \\
\text { di lingkungan tempat tinggal mereka sampai } \\
\text { kematian orang terdekat akibat kekerasan atau } \\
\text { cedera yang parah }\end{array}$ \\
\hline $\begin{array}{l}\text { Setiorini \& } \\
\text { Indrawati } \\
(2016)^{15}\end{array}$ & $\begin{array}{l}\text { Kualitatif } \\
\text { Fenomenologi }\end{array}$ & $\begin{array}{l}\text { Tiga orang dengan metode } \\
\text { pemilihan purposive } \\
\text { sampling }\end{array}$ & $\begin{array}{l}\text { Teknik eksplikasi dengan cara } \\
\text { observasi dan wawancara }\end{array}$ & $\begin{array}{l}\text { Tiga episode yang ditemukan adalah, } \\
\text { pengalaman child abuse, reaksi terhadap abuse } \\
\text { dan revitalisasi hubungan dengan keluarga } \\
\text { Pengalaman child abuse memiliki kesamaan } \\
\text { tema dengan orangtua melakukan kekerasan, } \\
\text { reaksi terhadap abuse memiliki tema munculnya } \\
\text { insight penyebab kekerasan }\end{array}$ \\
\hline $\begin{array}{l}\text { Crum \& } \\
\text { Morelan } \\
(2017)^{16}\end{array}$ & $\begin{array}{l}\text { Cross- } \\
\text { sectional }\end{array}$ & $\begin{array}{l}610 \text { orang responden } \\
\text { dengan criteria inklusi: } \\
\text { merupakan orang tua dari } \\
\text { anak berusia } 2-6 \text { tahun, baik } \\
\text { single parent maupun masih } \\
\text { memiliki pasangan }\end{array}$ & $\begin{array}{l}\text { Riset ini berkolaborasi dengan } \\
\text { Program pemerintah yang lain } \\
\text { (PACE) dimana orang tua akan } \\
\text { diobservasi selama 3-6 bulan } \\
\text { tentang bagaimana cara mereka } \\
\text { mengasuh anak }\end{array}$ & $\begin{array}{l}\text { Riset ini menemukan bahwa ternyata orang tua } \\
\text { yang stres potensial melakukan kekerasan pada } \\
\text { anak }\end{array}$ \\
\hline $\begin{array}{l}\text { Ellington } \\
(2017)^{17}\end{array}$ & Kuantitatif & $\begin{array}{l}\text { 17.000 responden yang } \\
\text { dibagi menjadi tiga } \\
\text { kelompok: } \\
\text { - Kekerasan } \\
\text { - Penelantaran } \\
\text { - Masalah dalam rumah } \\
\text { tangga }\end{array}$ & $\begin{array}{l}\text { Survei dilakukan dengan } \\
\text { meminta responden untuk } \\
\text { mengisi formulir yang berisikan } \\
\text { pertanyaan pertanyaan sesuai } \\
\text { tujuan penelitian }\end{array}$ & $\begin{array}{l}\text { Keluarga yang bermasalah berkontribusi } \\
\text { terhadap kekacauan neurodevelopment anak, } \\
\text { gangguan psikososial sehingga beresiko } \\
\text { terhadap masalah emosional, gangguan kejiwaan } \\
\text { dan perilaku agresif }\end{array}$ \\
\hline $\begin{array}{l}\text { Fox et all } \\
(2015)^{1}\end{array}$ & Cohort Study & $\begin{array}{l}22,575 \text { remaja di Tahanan } \\
\text { Remaja Florida yang pernah } \\
\text { mengalami trauma, } \\
\text { kekerasan, perilaku kriminal } \\
\text { dan faktor kekerasan lain }\end{array}$ & $\begin{array}{l}\text { Data dikumpulkan sejak } 1 \text { Januari } \\
2007 \text { sampai } 31 \text { Desember } 2012 \text {, } \\
\text { seluruh responden dibagi menjadi } \\
\text { tiga kelompok } \\
\text { Sebagai pelaku yang pernah } \\
\text { mengalami kekerasan } \\
\text { Pelaku tidak mengalami } \\
\text { kekerasan } \\
\text { Melakukan satu kali kekerasan }\end{array}$ & $\begin{array}{l}\text { Ketiga grup ini ditemukan selain memiliki } \\
\text { kondisi keluarga yang bermasalah dan } \\
\text { menyaksikan kekerasan dalam keluarga }\end{array}$ \\
\hline
\end{tabular}




\begin{tabular}{|c|c|c|c|c|}
\hline Artikel & Desain & Sampel & Prosedur pengumpulan data & Hasil \\
\hline $\begin{array}{l}\text { Baglivio et } \\
\text { all }(2017)^{6}\end{array}$ & $\begin{array}{l}\text { Cross sectional } \\
\text { study }\end{array}$ & \begin{tabular}{|l|}
11,557 remaja pria pelaku \\
kekerasan dengan kriteria \\
inklusi sudah mendapatkan \\
ijin dari hakim untuk \\
penahanan dirumah, \\
memperoleh program \\
pendidikan setara SMU, \\
menghadiri program \\
konseling yang disediakan \\
terapis berlisensi \\
\end{tabular} & $\begin{array}{l}\text { Intervensi perilaku kognitif, } \\
\text { kelompok pelatihan keterampilan } \\
\text { dan pencegahan penyalahgunaan } \\
\text { obat, manajemen emosi }\end{array}$ & $\begin{array}{l}\text { Hasil riset menemukan bahwa ada keterkaitan } \\
\text { antara penyalahgunaan obat, konsumsi alcohol } \\
\text { dan masalah dengan orangtua mempengaruhi } \\
\text { temperamen remaja serta pengalaman pernah di } \\
\text { tahan akan menimbulkan emosi negative pada } \\
\text { remaja }\end{array}$ \\
\hline $\begin{array}{l}\text { Magalhaes et } \\
\text { all. }(2017)^{18}\end{array}$ & $\begin{array}{l}\text { Qualitative } \\
\text { descriptive } \\
\text { study }\end{array}$ & $\begin{array}{l}8 \text { remaja yang terdiri dari } \\
\text { lima anak perempuan dan } \\
\text { tiga laki laki dengan kriteria } \\
\text { inklusi: berusia } 10-19 \text { tahun, } \\
\text { direkomendasikan oleh } \\
\text { Departemen Kesehatan } \\
\text { karena pernah mengalami } \\
\text { kekerasan dalam keluarga }\end{array}$ & $\begin{array}{l}\text { Metode ini mempraktikkan } \\
\text { bagaimana cara partisipan } \\
\text { menceritakan kejadian yang } \\
\text { disaksikan selama fase kekerasan } \\
\text { dalam wawancara mendalam, } \\
\text { semua detil, ekspresi dan bentuk } \\
\text { kekerasan yang dialami remaja } \\
\text { harus tercatat sebagai wujud dari } \\
\text { penelahaan ini. }\end{array}$ & $\begin{array}{l}\text { Penelitian ini menemukan bahwa remaja yang } \\
\text { menjadi subjek maupun objek pelaku kekerasan } \\
\text { pernah mengalami berbagai kekerasan daalam } \\
\text { keluarga seperti pemukulan dengan benda } \\
\text { tumpul bahkan senjata tajam, penelitian ini juga } \\
\text { mengingatkan bahwa mendidik anak dengan } \\
\text { kekerasan sangat tidak manusiawi sehingga } \\
\text { perlu rencana tindak lanjut dimasa yang akan } \\
\text { datang untuk menghentikan segala bentuk tindak } \\
\text { kekerasan khususnya pada anak dan remaja }\end{array}$ \\
\hline
\end{tabular}

\section{PEMBAHASAN}

Remaja yang tumbuh dengan trauma akibat kekerasan akan tumbuh menjadi pelaku kekerasan sebanyak $17,2 \%{ }^{(19)}$. Remaja yang tumbuh di dalam ruang lingkup keluarga atau orangtua yang sedang mengalami stress atau gangguan jiwa juga rentan terhadap gangguan perkembangan mental dan gangguan psikososial yang akan mengarah kepada masalah emosional dan perilaku yang agresif ${ }^{(16)}$. Perilaku yang agresif serta emosional yang sulit untuk dikendalikan akan menjadi awal terbentuknya perilaku kekerasan pada remaja.

Analisis Crum \& Morelan (2017) menemukan dalam risetnya bahwa ternyata orang tua yang stres potensial melakukan kekerasan pada anak, hal ini sejalan dengan peneltian Stimmel\&Cruise (2014) yang mendapatkan data dari hasil wawancara dengan 66 orang partisipan berusia remaja ditemukan sebanyak 86,4\% remaja pernah mengalami setidaknya satu peristiwa yang traumatis, $71 \%$ mengalami setidaknya dua peristiwa traumatis, remaja ini juga pernah menyaksikan kekerasan di lingkungan tempat tinggal mereka sampai kematian orang terdekat akibat kekerasan atau cedera yang $\operatorname{parah}^{(7,16)}$.

Ellington (2017) yang mewawancarai 17.000 responden dalam surveynya menemukan hasil bahwa keluarga yang bermasalah berkontribusi terhadap kekacauan neurodevelopment anak, gangguan psikososial sehingga beresiko terhadap masalah emosional, gangguan kejiwaan dan perilaku agresif ${ }^{(17)}$. Hal ini sejalan dengan penelitian CAADA (2014) yang tidak menemukan penyebab langsung terjadinya perilaku kekerasan pada remaja tetapi ada sejumlah faktor resiko yang terhubung dengan baik, diantaranya ada tiga poin utama yaitu penyalahgunaan narkoba dan alkohol, kesehatan mental dan yang terkait dengan temuan Ellington (2017) adalah hubungan dalam keluarga yang tidak baik ${ }^{(17,20)}$. Kedua riset ini didukung oleh penelitian Jones (2016) yang mengungkapkan bahwa remaja pelaku kekerasan berasal dari ayah dan ibu yang memiliki masalah kesehatan mental, penyalahgunaan zat zat terlarang bahkan terjadi pelecehan atau penelantaran dari orang tua remaja tersebut.

Penelitian yang dilakukan di empat Negara menemukan bahwa remaja mengakui empat jenis penganiayaan: pengabaian, penganiayaan fisik, penganiayaan psikologis, dan penganiayaan seksual; anak-anak dapat mengalami satu bentuk penganiayaan atau kombinasi lebih dari satu jenis ${ }^{(17)}$. Hal serupa juga diperoleh dalam hasil penelitian yang dilakukan oleh Magalhaes (2017) yaitu bahwa remaja yang menjadi subjek maupun objek pelaku kekerasan pernah mengalami berbagai kekerasan daalam keluarga seperti pemukulan dengan benda tumpul bahkan senjata tajam, penelitian ini juga mengingatkan bahwa mendidik anak dengan kekerasan sangat tidak manusiawi sehingga perlu rencana tindak lanjut dimasa yang akan datang untuk menghentikan segala bentuk tindak kekerasan khususnya pada anak dan remaja ${ }^{(18)}$.

Penelitian yang dilakukan di Indonesia oleh Setiorini dan Indrawati (2016) menemukan ada faktor lain yang disebut dengan emphatic complex pada anak anak yang mengalami kekerasan dalam keluarga dari orang terdekatnya $^{(15)}$. Orang tua sering menggunakan hukuman fisik untuk menghentikan anak melakukan hal tidak diinginkan, hal ini menyebabkan anak sangat sedikit mendapatkan hubungan yang hangat dan menyenangkan dengan orangtuanya. Karena tidak memiliki hubungan yang baik dengan kedua orangtuanya, anak tidak mampu mengadakan hubungan sosial yang hangat dan ramah dengan lingkungan sekitar. Akhirnya anak melakukan reaksi coping meninggalkan rumah dan timbul didalam dirinya dorongan untuk melakukan kekerasan terhadap orang lain. 


\section{KESIMPULAN}

Berdasarkan hasil telaah ke tujuh artikel diatas maka dapat disimpulkan bahwa faktor faktor yang memicu timbulnya resiko seorang remaja melakukan kekerasan antara lain karena, berawal dari lingkungan keluarga khususnya orangtua yang sedang mengalami stres atau tekanan dari lingkungan atau pekerjaan serta harapan yang tidak tercapai, Hasil riset menemukan bahwa ada keterkaitan antara penyalahgunaan obat, konsumsi alkohol dan masalah dengan orangtua mempengaruhi temperamen remaja serta pengalaman pernah di tahan akan menimbulkan emosi negatif pada remaja. Karena itu remaja khususnya generasi muda saat ini khususnya di Indonesia sedang gencar dilakukan pencegahan terhadap narkotika dan obat obatan terlarang. Secara penelitian bahan bahan seperti alcohol dan obat obatan terlarang tidak hanya merusak secara fisik tetapi juga mental remaja.

\section{DAFTAR PUSTAKA}

1. Fox B et all. Trauma changes everything: Examining the relationship between adverse childhood experiences and serious, violent and chronic juvenile offenders. Elsevier. 2015;1-11.

2. Ryan J, William A, Courtney M. Adolescent neglect, juvenile delinquency and the risk of recidivism. Springer Sci. 2013;(42):454-65.

3. Kurniasari Yanuar Farida Wismaayanti Irmayani Husmiati Nurdin Widodo Badrun Susantyo Konsultan A, Gambit Praptoraharjo Kerjasama Kementerian Sosial Kementerian Pemberdayaan Perempuan Dan Perlindungan Anak Badan Perencanaan Pembangunan Nasional I. Survey Kekerasan Terhadap Anak Indonesia Tahun 2013. Kementeri Sos. 2013;

4. Pusdatin. Kekerasan terhadap anak dan remaja. Pusay Data dan Informasi Kementrian Kesehatan RI; 2019.

5. Dierkhising et all. Trauma histories among justice-involved youth: Findings from the national child traumatic stress network. Eur J Psychotraumatol. 2014;4-10.

6. Baglivio M, Epps N, Swartz K, Huq M, Hardt N. The prevalence of adverse childhood experiences (ACE) in the lives of juvenile offenders. J Juv Justice. 2014;1009-29.

7. Stimmel MA, Cruise KR, Ford JD, Weiss RA. Trauma exposure, posttraumatic stress disorder symptomatology, and aggression in male juvenile offenders. Psychol Trauma Theory, Res Pract Policy. 2014;6(2):184-91.

8. Sulaiman M, Halidi R. Anak berhadapan hukum tertinggi, potret buram perlindungan anak Indonesia. 2019.

9. Aadnanes M, Gulbrandsen L. Young people and young adults"experiences with child abuse and maltreatment: Meaning making, conceptualizations and dealing with violence. J Sage. 2018;594-610.

10. Tisdale A. The effects of incarceration on juveniles in prison and during reentry. J Univ Tennesse. 2019;1-8.

11. Dahlbo M, Jakobsson L, Lundqvist P. Keeping the child in focus while supporting the family: Swedish child healthcare nurses experiences of encountering families where child maltreatment is present or suspected. J Child Heal Care. 2017;21(1):103-11.

12. Tuliah S. Kajian motif pelaku kekerasan seksual terhadap anak melalui modus operandi di lingkungan keluarga. eJOurnal Sosiatri-Sosiologi. 2018;6(2):1-17.

13. Caneira L, Myrick K. Diagnosing child abuse: The role of the nurse practitioner. J Nurse Pract. 2015;640-6.

14. Lines L, Hutton A, Grant J. Integrative review: Nurses roles and experiences in keeping children safe. J Nurs Midwifery. 2016;302-33.

15. Indrawati E., Setiorini D. Pengalaman hidup korban child abuse dari keluarga broken home: Studi kualitatif fenomenologis pada dewasa awal. J Empati. 2016;450-2.

16. Crum K, Moreland A. Parental stress and children's social behavioral outcomes: The role of abuse potential overtime. ProQuest LLC. 2017;3067-78.

17. Ellington E. Psychiatric Nursing's role in child abuse. ProQuest LLC. 2017;16-20.

18. Magalhaes et all. The expression of intrafamily violence: Adolescent oral histories. Scopus. 2017;1-9.

19. Vagi KJ, Olsen, E. O. M. Basile KC, Vivolo-Kantor AM. Teen dating violence (physical and sexual) among US high school students: Findings from the 2013 national youth risk behavior survey. JAMA Pediatr. 2015;5(169):474-82.

20. Co-ordinated Action Against Domestic Abuse (CAADA). In plain sight: The evidence from children exposed to domestic abuse. Co-ordinated Action Against Domestic Abuse (CAADA). 2014. 